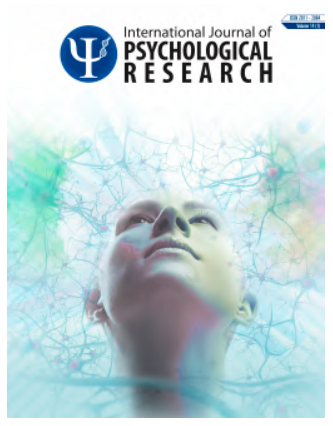

Vol $14, \mathrm{~N}^{\circ} 1$

https://revistas.usb.edu.co/index.php/IJPR ISSN 2011-2084

E-ISSN 2011-7922

\section{OPEN ACCESS}

Manuscript received: $04-05-2020$

Revised: 31-08-2020

Accepted: 10-02-2021

${ }^{\star}$ Corresponding author:

Lizzette Gómez-de-Regil.

Email: gomezderegil@gmail.com

Copyright: ๑2021. International Journal of Psychological Research provides open access to all its contents under the terms of the license creative commons AttributionNonCommercial-NoDerivatives 4.0 International (CC BY-NC-ND 4.0)

Declaration of data availability: All relevant data are within the article, as well as the information support files.

Conflict of interests: The authors have declared that there is no conflict of interest.

How to Cite:

Romero Acosta, K., Gómez-de-Regil, L., Lowe, G. A., Lipps, G. E. \& Gibson, R. C. (2021). Parenting Styles, Anxiety and Depressive Symptoms in Child/Adolescent. International Journal of Psychological Research, 14(1), 1232. https://doi.org/10.21500/20112084.4704

\title{
Parenting Styles, Anxiety and Depressive Symptoms in Child/Adolescent
}

Estilos parentales, ansiedad y depresión en niños y adolescentes

Kelly Romero-Acosta ${ }^{1}$ (i), Lizzette Gómez-de-Regil ${ }^{2, \star(i),}$ Gillian A. Lowe ${ }^{3}$ id , Garth E. Lipps ${ }^{4}$ id, Roger C. Gibson ${ }^{3}$

${ }^{1}$ Grupo de investigación Dimensiones Humanas. Departamento de investigación psicológica, Facultad de humanidades y educación. Corporación Universitaria del Caribe CECAR. Sincelejo, Colombia.

${ }^{2}$ Hospital Regional de Alta Especialidad de la Península de Yucatán. Fraccionamiento Altabrisa. Mérida, Yucatán, México.

${ }^{3}$ Department of Community Health and Psychiatry. The University of the West Indies Mona. Kingston, Jamaica.

${ }^{4}$ Department of Sociology, Psychology and Social Work. The University of the West Indies Mona. Kingston, Jamaica.

\section{Abstract.}

Objective: To analyse the possible direct and interactive associations of sex, age and parenting styles with symptoms of depression and anxiety. Methods: In this cross-sectional study, 710 students ranging from 8 to 13 years (mean age 10.8 years $[ \pm 0.75])$, the most of them males $(n=422,59.4 \%)$, completed three screening instruments: a parenting practices scale and two self-reports for evaluating anxiety and depressive symptoms. Two hierarchical multiple regression analyses were performed. Results: Authoritative (38.6\%) and neglectful $(38 \%)$ parenting styles were predominant. Symptoms of depression $-F(3,706)=3.12, p=.03-$ and anxiety $-F(3,706)=2.83, p=.4-$ differed by parenting styles. Students with a neglectful parenting style reported significant lower generalized anxiety symptoms than those whose parents used authoritative parenting. Clinical implications: Children ages 8 to 13 years-old with authoritative parenting style should be evaluated for possible presence of generalized anxiety symptoms.

Resumen.

Objetivos: Analizar las posibles asociaciones entre sexo, edad y estilos de crianza con síntomas de depresión y ansiedad. Método: En este estudio transversal participaron 710 estudiantes entre 8 y 13 años (con una edad promedio de $10.8[D E=0.75])$, la mayoría hombres $(n=422,59.4 \%)$, los cuales respondieron tres instrumentos de cribado: una escala de prácticas parentales y dos autoinformes para evaluar síntomas de ansiedad y de depresión. Se llevaron a cabo dos regresiones múltiples. Resultados: Los estilos parentales predominantes fueron el autoritativo (38.6\%) y el negligente $(38 \%)$. Los síntomas depresivos $-F(3,706)=3.12, p=.03-\mathrm{y}$ ansiosos $-F(3,706)=2.83, p=.4-$ se relacionaron de manera diferente entre los estilos parentales. El estilo parental negligente se asoció con menos ansiedad generalizada que el estilo parental autoritativo. Implicaciones clínicas: Los niños de 8 a 13 años con estilo de crianza autoritario podrían ser evaluados para detectar la posible presencia de síntomas de ansiedad generalizada.

\section{Keywords.}

Parenting, depression, anxiety, Colombian, children, adolescents.

Palabras Clave.

Estilos parentales, depresión, ansiedad, colombianos, niños, adolescentes. 


\section{Introduction}

Parenting styles are a group of integrated practices that help to determine how families face the demands of the environment (Baumrind, 1971; Smetana, 2017). These practices may influence the mental health of children and adolescents, as well as their academic, social, and emotional development (Boudreault-Bouchard et al., 2013; Brassell et al., 2016; Diaconu-Gherasim \& Măirean, 2016; Lipps et al., 2012; Smetana, 2017). Internalizing symptoms (e.g. depression, anxiety, and somatic complaints) and externalizing symptoms (e.g. aggression and behavioural problems) have shown some association with parenting styles. However, some of the relevant research findings are inconsistent (Pinquart, 2017): they have been derived from different models of understanding parenting styles, and there is some evidence of cultural variability (Rothenberg et al., 2020). There are few studies performed in the Colombian population that explore parenting styles and internalizing symptomatology.

\subsection{Parenting Practices}

Baumrind $(1966,1971,1996)$ was the first to describe three parental practices which parents use with their children: authoritarian (low warmth and high control), authoritative (high warmth and high control), and permissive (high warmth and low control). Later, a fourth parenting style, the rejecting-neglectful style (low warmth and low control), was added (Baumrind, 1966, 1971, 1996; Boudreault-Bouchard et al., 2013; Brassell et al., 2016; Diaconu-Gherasim \& Măirean, 2016; Lipps et al., 2012). Since this initial categorization of parenting styles, other models have emerged. Examples from recent research include the concepts of rejection (Măirean \& DiaconuGherasim, 2020), and democratic and ambiguous parenting styles (Moreno-Méndez et al., 2020).

There has been significant research on the association between parental style and several outcomes in children and adolescents. For instance, Diaconu-Gherasim and Măirean (2016) found that parenting styles were associated with goal orientations and academic achievement in adolescents aged between 14 and 18 years. Scharf et al. (2016) found that moderately-high levels of internalizing symptoms (anxiety, depression, and withdrawal) were associated with high levels of harsh parenting. Smetana (2017) pointed out in this respect that harshness is one of the main characteristics of authoritarian parenting, as well as physical yelling, scolding, shaming, among others. Exposure to parental verbal aggression has been associated with increased levels of depressive and anxiety symptoms (Polcari et al., 2014). In contrast, an authoritative parenting style has been associated with lower levels of depressive symptoms and this phenomenon is maintained over time (Liem et al., 2010; Steinberg et al., 1994).

Apart from the influence of parenting style on childrens perceptions, emotions, and behaviour, it has been proposed that these characteristics in children also influ- ence parenting style. Pinquart (2017) conducted a metanalyses of longitudinal studies and demonstrated that the presence of internalising symptoms predicted declines in both parental warmth and authoritative parenting.

\subsection{Demographic Factors}

Previous research has indicated that associations between internalizing symptoms and parenting style are more marked among girls than boys and among older than younger children (Van Der Bruggen et al., 2008). This is also reflective of the higher prevalence of internalizing symptoms among these groups. In school-based research, it is not uncommon to encounter some children who are unusually young or old for their gradelevel. Children in this situation may not have a strong sense of belonging to their grade-level peers and would therefore be at higher risk than others for internalizing symptoms, given the association between a low sense of belonging and the presence of internalizing symptoms (de Moor et al., 2018).

\subsection{Cultural Factors}

Cultural factors are an important consideration for predicting how parental style and childrens emotional and behavioural experiences may be associated with each other. For example, Varela et al. (2009) reported that hostile parenting is much less associated with anxiety among Latin American adolescents than their European counterparts. It is therefore important to conduct research in specific cultures to determine what types of associations are applicable to them.

\subsection{The Impact of Internalizing Symptoms on Childrens Lives}

All of the above points to the fact that parenting style may influence the presence of emotional problems, such as anxiety and depression. Both psychopathologies have been found to be related to high levels of impairment and frequent use of mental health services early in life (Duchesne et al., 2008). Anxious students may be more likely to anticipate failure, to perceive themselves negatively as learners, and to consider that they have little control over everything related to their learning; these thoughts may be present in potentially anxiogenic situations, leading to the adoption of avoidance behaviours and generating emotional distress. These characteristics may influence their functional impairment in school to the point of no completing it (Duchesne et al., 2008).

Depressive symptoms, even under the threshold of a diagnosis of major depression, may show a direct impact on daily life activities, especially in school and with friends, and may result in an elevated use of mental health services (Wesselhoeft et al., 2013). Depressive symptoms have been related to a reduction in academic self-efficacy, an ineffective use of learning strategies, and low levels of motivation and self-esteem, which, in turn, 
may produce a tendency to drop out from school. Depressive symptomatology may generate deficits in shortterm memory and problems with the execution of activities that require information processing, as well as altered sleep and weight patterns, which may influence the ability to concentrate on school work (Masi et al., 2000).

\subsection{Internalizing Symptoms among Colombian Youth}

From research that has employed screening instruments (as opposed to diagnostic methods), the prevalence of internalizing symptoms in Colombian children has been estimated to be between $8.9 \%$ and $26.1 \%$ (Abello et al., 2014; Velez-Gomez et al., 2013; Vinaccia et al., 2006). Using similar methods, other studies have estimated the prevalence of anxiety symptoms to be between $28.3 \%$ and 71.1\% (Ospina-Ospina et al., 2011; Pérez Vásquez et al., 2016).

In Colombia, the presence of depressive and anxiety symptoms has been studied considering some variables such as sociodemographic characteristics, neuropsychological variables, levels of exposure to violence, school achievement, and forced displacement (Argumedos et al., 2014). There has also been some research on parenting and internalizing symptoms in Colombian. Castillo, Carpintero, et al. (2015) examined 45 parents and their children, and found that among support, satisfaction with parenting, commitment, communication, discipline, and autonomy, commitment was the only parental attitude related to anxiety symptomatology. Moreno-Méndez et al. (2020) have examined democratic, ambiguous, authoritarian and permissive parenting styles among 422 Colombian parents and their children and found the permissive style to be associated with anxiety and depression.

\subsection{Objectives}

In Colombia, while past research (e.g. Argumedos et al., 2014) has examined the association of internalizing symptoms with sociodemographic characteristics, neuropsychological variables, exposure to violence, school achievement, and forced displacement, only some studies (e.g. Castillo, Carpintero, et al., 2015; Moreno-Méndez et al., 2020) have related parental practices to internalizing symptoms. Yet, they did not examine the effects of any of the four classical parental practices described by Baumrind; neither did they examine parenting from the childs perspective. The present study aimed to: 1) explore the perceptions of parental practices in a sample of Colombian children; and 2) analyse the possible direct and interactive associations of sex, age, and parenting styles with depression and anxiety. More specifically, we hypothesized that, in keeping with previous research, children who perceived an authoritative parenting style would have fewer self-reported features of depression and anxiety than children who perceived other types of parenting styles. We also hypothesized that children of older age, female sex, and inappropriate age for grade-level would be more likely than others to have internalizing symptoms overall and that associations between internalizing symptoms and parenting style would be more apparent among these groups.

\section{Method}

\subsection{Sample}

\subsubsection{Sociocultural aspects of Sincelejo, Colombia}

Sincelejo is a city within the region/department of Sucre, near the northern coast of Colombia. The main income generating activities are farming and small businesses (DANE, 2020). Most of the families are nuclear families with two parent headed homes. Often, people from the surrounding rural farming communities migrate to Sincelejo in search of better opportunities for employment and/or education. There are over 315 public schools and 14 several private schools in Sincelejo (Ministerio de Tecnologías de la Información y las Comunicaciones, 2020).

More than half $(n=422,59.4 \%)$ of the sample were males (Table 1 ). On average participants were 10.8 years $( \pm 0.75 y e a r s)$ and ranged in age from 8 to 13 years. The majority of students had parents who had secondary education or less and worked in manual or skilled labour jobs (Table 1). All of the students were in the fifth grade with 539 of them or $75.9 \%$ attending public primary schools. In Colombia, primary school includes grades one to five, while basic secondary school includes grades six to nine, mid-secondary includes grades ten to eleven; thus, participants were attending the last grade of primary school. Participants were deliberately sampled from both public and private schools, to obtain a sample of participants from across all social classes with a wide variance in parental educational levels and parental occupations (Table 1). The inclusion criteria consisted of all grade 5 students who were present at school on the day of data collection and whose parents gave written consent for them to take part in the study. Additionally, the students had to give their (students) written assent to participate. The exclusion criteria consisted of students from all the other grades, students who were absent from school on the day of data collection, youth whose parents did not consent for them to participate and who did not give their assent to participate in the study.

\subsection{Measurements}

\subsubsection{Socio-demographic Characteristics}

Adolescents completed four questions that collected data on their mothers' and fathers' highest level of education (closed ended) and current occupation (open ended). These questions were included as they are key variables needed to calculate various indices of socio-economic status and social class. For the current study, only the open-ended questions on mothers' and fathers' current occupation were used. The occupations reported by adolescents for their mothers and fathers were coded 
Table 1

Demographic Characteristics of the Sample

\begin{tabular}{|c|c|c|}
\hline & $N$ & $\%$ \\
\hline \multicolumn{3}{|l|}{ Students' Age } \\
\hline 8 & 3 & .4 \\
\hline 9 & 63 & 8.9 \\
\hline 10 & 451 & 63.5 \\
\hline 11 & 149 & 21 \\
\hline 12 & 39 & 5.5 \\
\hline 13 & 5 & 0.7 \\
\hline \multicolumn{3}{|l|}{ Students' Sex } \\
\hline Female & 288 & 40.6 \\
\hline Male & 422 & 59.4 \\
\hline \multicolumn{3}{|l|}{ Type of School } \\
\hline Public & 539 & 75.9 \\
\hline Private & 89 & 12.5 \\
\hline Missing & 82 & 11.5 \\
\hline \multicolumn{3}{|l|}{ Mother's Occupation } \\
\hline Farm Labourers-Menial Service Workers & 346 & 48.7 \\
\hline Unskilled Workers & 73 & 10.3 \\
\hline Machine Operators \& Semi-Skilled Workers & 103 & 14.5 \\
\hline Smaller Business Owners, Skilled Manual Workers, Craftsmen \& Tenant Farmers & 36 & 5.1 \\
\hline Clerical and Sales Workers, Small Farm and Business Owners & 46 & 6.5 \\
\hline Technicians, Semi-Professionals, Small Business Owners & 80 & 11.3 \\
\hline Smaller Business Owners, Farm Owners, Managers, Minor Professionals & 16 & 2.3 \\
\hline Administrators, Lesser Professionals, Proprietors of Medium Sized Businesses & 10 & 1.4 \\
\hline \multicolumn{3}{|l|}{ Father's Occupation } \\
\hline Farm Labourers-Menial Service Workers & 69 & 9.7 \\
\hline Unskilled Workers & 195 & 27.5 \\
\hline Machine Operators \& Semi-Skilled Workers & 132 & 18.6 \\
\hline Smaller Business Owners, Skilled Manual Workers, Craftsmen \& Tenant Farmers & 90 & 12.7 \\
\hline Clerical and Sales Workers, Small Farm and Business Owners & 130 & 18.3 \\
\hline Technicians, Semi-Professionals, Small Business Owners & 55 & 7.7 \\
\hline Smaller Business Owners, Farm Owners, Managers, Minor Professionals & 25 & 3.5 \\
\hline Administrators, Lesser Professionals, Proprietors of Medium Sized Businesses & 14 & 2.0 \\
\hline \multicolumn{3}{|l|}{ Mother's Education } \\
\hline Kindergarten or Less & 63 & 8.9 \\
\hline Primary School & 75 & 10.6 \\
\hline High School Graduate & 245 & 34.5 \\
\hline Trade/Vocational Certificate & 81 & 11.4 \\
\hline Bachelors Degree & 191 & 26.9 \\
\hline \multicolumn{3}{|l|}{ Father's Education } \\
\hline Kindergarten or Less & 80 & 11.3 \\
\hline Primary School & 79 & 11.1 \\
\hline High School Graduate & 244 & 34.4 \\
\hline Trade/Vocational Certificate & 49 & 6.9 \\
\hline Bachelors Degree & 201 & 28.3 \\
\hline Graduate Degree & 57 & 8.0 \\
\hline
\end{tabular}


into occupational categories listed on the International Standard Classification of Occupations (ISCO88; International Labor Office, 1990) and then coded into scores on the International Socio-Economic Index of Occupational Status (Ganzeboom \& Treiman, 1996). Ganzeboom and Treiman conceptualized The International Socio-Economic Index of Occupational Status is conceptualized (1996) as a measure of socio-economic status that converts the features of occupations and education into income. A family score on the International SocioEconomic Index of Occupational Status was created by averaging the scores assigned to adolescents' mothers and fathers.

Adolescents also completed a single open-ended question asking their age on their last birthday. This question was used to determine if they fell into the expected ages for children attending grade 5 (10 to 11 years of age). Based on adolescents' responses, students were classified into two groups: age-grade consistent if they were between 10 to 11 years of age or age-grade inconsistent if they were between 8 to 9 years of age or 12 to 13 years of age.

\subsubsection{Parenting Style}

Adolescents' perceptions of their parents parenting practices during the past 6 months was collected using the Parenting Practices Questionnaire (Lempers et al., 1989). This self-report 29-item instrument assesses parental nurturance (14 items), monitoring (5 items), and inconsistent discipline (10 items) using a 5-point Likert scale ranging from 1 ("never") to 5 ("very often"). In the development sample (Lempers et al., 1989), the overall measure, collapsing across all sub-scales, had a coefficient alpha of .80. In this sample of Colombian adolescents, collapsing across all sub-scales, the measure had good internal consistency reliability $(\alpha=.90)$ for the overall measure, as well as good internal consistency reliability for the nurturance sub-scale $(\alpha=.92)$ and the monitoring sub-scale $(\alpha=.80)$, and fair internal consistency reliability for the inconsistent discipline sub-scale $(\alpha=.70)$. Following Lipps et al. (2012), parenting styles were classified using the median values for nurturance and monitoring. Cases where students perceived their parents to be above the median for both nurturance and monitoring were classified as authoritative parenting, while cases where both nurturance and monitoring were below or equal to the median were classified as neglectful parenting style. Cases where nurturance scores were above the median, but monitoring scores were below or equal to the median were classified as permissive parenting. Cases where monitoring scores were above the median, but nurturance scores were below or equal to the median were classified as authoritarian parenting.

\subsubsection{Depression and Anxiety}

From the Revised Child Anxiety and Depression scale (RCADS; Chorpita et al., 2000), the depressive symp- toms and the generalized anxiety symptoms sub-scales were used. All items were presented in a Likert format ranging from 0 ("never") to 3 ("always"). The depressive symptoms subscale in the development sample had an internal consistency reliability of .80 for clinical samples and .79 for school based samples of children 6 to 18 years of age (Boudreault-Bouchard et al., 2013; Ebesutani et al., 2012; Smetana, 2017). In this sample, both the 10-item depressive symptoms $(\alpha=.71)$ and the 6 -item $\operatorname{GAD}(\alpha=.70)$ subscales showed an acceptable level of internal consistency reliability.

\subsection{Procedure}

Prior to the commencement of this study, an estimate of the required sample size was executed using G-Power (version 3.1.9.7) software, considering a statistical power of .95 , an alpha error rate of .05 , and a medium effect size $\left(f^{2}=.15\right)$. A medium effect size was chosen for the sample size calculations based on past research using Caribbean samples (Lipps et al., 2012; Lowe et al., 2009). Results of the analysis indicated that a sample of 600 participants was required.

This cross-sectional study was approved by the Research and Ethical Committee of the "Corporación Universitaria del Caribe CECAR" and performed in Sincelejo, district of Sucre, Colombia. The collection data started on May 15 ${ }^{\text {th }}, 2016$, and finished on August 26 $6^{\text {th }}, 2016$. To obtain the participating schools, a list of schools in Sincelejo was obtained from the Secretary of Education in 2015. The list consisting of 45 schools was divided into public and private schools and each school was assigned a number according to whether it was a public or private school. Using a table of random numbers, schools from private and public categories were chosen. Seventeen schools were initially randomly selected to take part in the study from a total of 45 . The project was presented to each of the 17 school principals and the academic staff. From the initial 17 schools selected to take part, 13 schools (76.5\%) agreed to collaborate. Four schools did not agree to participate: one was a private school and three were public. From a total of 861 students invited to participate, almost $82.4 \%(n=710)$ of the students agreed to collaborate handing in signed informed assent and informed parental consent forms. The high participation of students was due to diligent efforts to recruit participants with researchers visiting each classroom many times during the week. If a student indicated that they forgot the parental consent at home or that they lost it, we came back the next day or provided students with another parental consent to be signed by parents.

In a single school day, research assistants provided a synopsis of the study to the participants and administered the questionnaires to the students, at the beginning of their regular class time. Students completed a questionnaire, which contained eight psychological mea- 
sures: School Engagement (Norris et al., 2003), the Numeric 0 to 10 Anxiety Scale (Crandall et al., 2007), the Visual Analogue Anxiety Scale (Bringuier et al., 2009), Revised Child Anxiety \& Depression Scale - Generalized Anxiety Sub-Scale (Chorpita et al., 2000), Revised Child Anxiety \& Depression Scale - Depression SubScale (Chorpita et al., 2000), The Adolescent Depression Rating Scale - ADRS (Revah-Levy et al., 2007), the Kutcher Adolescent Depression Scale (Brooks, 2004), the Parenting Practices Scale (Lempers et al., 1989), and a series of demographic question. Completion of the questionnaire took approximately 20 minutes. The current project only used three of these measures (Revised Child Anxiety \& Depression Scale - Generalized Anxiety Sub-Scale, Revised Child Anxiety \& Depression Scale - Depression Sub-Scale, and the Parenting Practices Scale). Confidentiality and freedom to decline participation before or after responding to the questionnaires were guaranteed. Prior to the day of data collection, each participant was given a letter addressed to his/ her parents, requesting approval to participate, and noting the possibility to withdraw from the study at any time. Participants could sit in their classrooms while the self-reporting data collection instruments were administered. Their class teachers, as well as the research assistants, supervised them throughout the process.

\subsection{Statistical analysis}

To ensure the accuracy of the statistical estimates, the data were screened for normality, linearity, outliers, and missing data, prior to the formal data analyses. Those variables which had missing values that were involved in the planned analyses were replaced using ExpectationMaximization imputation.

A series of simple statistical analyses were conducted prior to the formal, planned analyses to examine the potential biasing effects of sex, type of school, age-grade consistency (on-track versus off-track), parental education, parental occupation, and socio-economic status on depression and anxiety. Past research in the Caribbean has found these variables to be related to depression (De La Haye et al., 2010; Jules et al., 2020; Lipps et al., 2012; Lipps et al., 2010; Lipps et al., 2009; Lowe et al., 2009; Maharaj et al., 2008). Independent samples t-tests were used to explore the potential biasing effects of sex, type of school, and age-grade consistency on RCADS depression and anxiety scores. One-way ANOVA's were used to explore the potential biasing effects of parental education, parental occupation, on RCADS depression and anxiety scores. One-Way ANOVA's were also conducted to examine differences on RCADS depression and anxiety scores by parenting style. Pearsons ProductMoment correlations explored the association between socio-economic status and students RCADS depressive and anxiety scores.
Formal, planned data analyses of the hypotheses were conducted using hierarchical multiple regression analyses. These hierarchical multiple regression analyses explored the possible interactive effect of parenting styles with sex on levels of depression and anxiety. At the first stage of the regression analysis, sex was entered into regression equation as dummy coded variable with females serving as the reference groups. At the second stage of analysis, the three variables representing parenting styles were entered into regression equation as dummy coded variables with authoritative parenting serving as the reference group. At the third stage of analysis, three separate variables representing the interaction of sex by parenting styles were entered into the regression equation. For all regression analyses, depression and anxiety served as the dependent variables, while sex, the three dummy coded variables representing type of parenting, and the three separate terms representing the interactions of sex by type of parenting, served as the independent variables.

\section{Results}

\subsection{Preliminary Analyses of Biasing Factors}

In general, with the exception of sex and generalized anxiety, demographic and school related factors had little statistically significant associations to children's symptoms of depression and anxiety. There were no statistically significant differences in students RCADS-MDD scores by sex -t(708) $=-.02, p=.98-$, by age-grade consistency - $t(708)=.42, p=.68-$, by type of school attended - $t(708)=-.18, p=.85-$, mothers' occupation $-F(7,702)=.84, p=.55-$, fathers' occupation $F(7,702)=.57, p=.78-$, mothers' education $-F(5,704)$ $=1.29, p=.27$ - and fathers' education $-F(5,704)=$ $.43, p=.83-$. Similarly, there were no statistically significant differences in students RCADS-Generalized Anxiety scores by age-grade consistency $-t(708)=.05$, $p=.96-$, by type of school attended $-t(708)=.11, p=$ $.91-$, mothers' occupation $-F(7,702)=.91, p=.50-$, fathers' occupation $-F(7,702)=.87, p=.53-$, mothers' education $-F(5,704)=2.02, p=.07-$, and fathers' education $-F(5,704)=2.13, p=.06-$. However, students did differ in RCADS-Generalized Anxiety scores by sex $-t(708)=-2.47, p=.01-$, with boys reporting slightly higher scores RCADS-Generalized Anxiety scores (10.82) than girls (10.11). ISEI Socio-economic status scores were not correlated with RCADS-MDD scores for mothers $(r=-.01, p=.87)$, fathers $(r=-.02$, $p=.63)$ or the family average ISEI socio-economic status scores $(r=-.01, p=.70)$. Similarly, ISEI Socioeconomic status scores were not correlated with RCADSGeneralized Anxiety scores for mothers $(r=.03, p=.48)$, fathers $(r=-.04, p=.32)$ or the family average ISEI socio-economic status scores $(r=-.01, p=.89)$. 


\subsection{Analyses of Parenting Style}

The pupils mainly reported that their parents used either authoritative $(38.6 \%)$ or neglectful $(38 \%)$ parenting styles (Table 2). RCADS-MDD symptoms of depression differed by parenting styles $-F(3,706)=3.12, p=$ .03. However, Bonferroni post-hoc tests did not indicate which types of parenting differed. RCADS-GAD anxiety scores also differed by parenting style $-F(3,706)=$ $2.83, p=.4-$. Bonferroni post-hoc tests indicated that students whose parents used a neglectful parenting style, reported significant lower mean RCADS generalized anxiety scores than those whose parents used authoritative parenting (Table 3).

Table 2

Frequency of Parenting Styles

\begin{tabular}{lcc}
\hline Parenting Style & $n$ & $\%$ \\
\hline Authoritative & 275 & 38.6 \\
Authoritarian & 86 & 12.1 \\
Permissive & 80 & 11.3 \\
Neglectful & 270 & 38.0 \\
\hline
\end{tabular}

Table 3

Differences in Depressive Symptoms and Anxiety Symptoms by Parenting Style

\begin{tabular}{|c|c|c|c|}
\hline Parenting & & $\begin{array}{c}\text { Mean } \\
\text { RCADS- } \\
\text { MDD } \\
\text { Depression }\end{array}$ & $\begin{array}{c}\text { Mean } \\
\text { RCADS- } \\
\text { GADS } \\
\text { Anxiety }\end{array}$ \\
\hline $\begin{array}{l}\text { Authoritative } \\
N=274\end{array}$ & $\begin{array}{l}\text { Mean } \\
S D\end{array}$ & $\begin{array}{c}6.29 \\
(4.39)\end{array}$ & $\begin{array}{l}11.01^{\mathrm{a}} \\
(3.59)\end{array}$ \\
\hline $\begin{array}{l}\text { Authoritarian } \\
N=86\end{array}$ & $\begin{array}{l}\text { Mean } \\
S D\end{array}$ & $\begin{array}{c}7.44 \\
(4.55)\end{array}$ & $\begin{array}{l}10.43 \\
(3.33)\end{array}$ \\
\hline $\begin{array}{l}\text { Permissive } \\
N=80\end{array}$ & $\begin{array}{l}\text { Mean } \\
S D\end{array}$ & $\begin{array}{c}6.06 \\
(4.25)\end{array}$ & $\begin{array}{l}10.53 \\
(3.69)\end{array}$ \\
\hline $\begin{array}{l}\text { Neglectful } \\
N=270\end{array}$ & $\begin{array}{l}\text { Mean } \\
S D\end{array}$ & $\begin{array}{l}7.16 \\
(4.45)\end{array}$ & $\begin{array}{l}10.08^{\mathrm{b}} \\
(4.00)\end{array}$ \\
\hline $\begin{array}{l}\text { Missing } \\
N=82\end{array}$ & $\begin{array}{l}\text { Mean } \\
S D\end{array}$ & $\begin{array}{l}7.05 \\
(4.81)\end{array}$ & $\begin{array}{l}10.93 \\
(4.08)\end{array}$ \\
\hline
\end{tabular}

Note. The difference between Neglectful versus $\mathrm{Au}-$ thoritative RCADS-GAD means is statistically significant.

\subsection{Association of Students Sex and their Caregivers Parenting Styles with RCADS Depression and Anx- iety Scores}

Two sets of hierarchical multiple regression analyses were conducted to examine the direct and interactive associations of sex and parenting styles to both students RCADS-MDD scores and their RCADS-GAD scores.

In the first hierarchical regression analysis, a dummy coded predictor for sex (reference group $=$ females) was first entered into the regression equation as a predictor of RCADS-MDD scores. At the second stage of analysis, the three dummy coded predictors for parenting styles (reference group = authoritarian parenting) were entered into the regression analysis as predictors of RCADS-MDD scores. At the final stage of analysis, the interactions of sex by parenting styles as predictors of major depression scores entered last into the regression equation. Results of the regression analysis found that at the first stage of the regression analysis, sex was not a significant predictor of RCADS-MDD scores, while at the second stage of analysis, controlling for sex, children who reported that their parents used authoritative $(t=2.104, p<.05)$ or permissive parenting $(t=2.305, p<.05)$ styles reported lower RCADS-MDD scores than those whose parents used an authoritarian parenting style. At the third stage of analysis, the interactions of sex by type of parenting styles were all non-significant (Chg R2 =.00, $p>.05$; Table 4$)$.

In the second hierarchical regression analysis, a dummy coded predictor for sex (reference group $=$ females) was first entered into the regression analysis, followed by three dummy coded predictors for parenting styles (reference group $=$ authoritarian parenting) with the interactions of sex by parenting styles entered last as predictors of generalized anxiety scores. Sex had a statistically significant relationship with symptoms of generalized anxiety disorder $(t=2.47, p<.05)$, such that males reported higher symptoms of anxiety than females. Controlling for sex, parenting practices were significantly associated with students RCADS-GAD scores $(t=2.47, p<$ .05 , Table 5$)$. However, the regression analyses did not indicate where the differences in parenting styles were. The interactions of sex by type of parenting were all non-significant (Chg R2 =.003, $p>.05$; Table 5).

\section{Discussion}

This study provides information regarding students perceptions of parenting practices reported by a sample of Colombian students and its possible direct and interactive association with sex and age on their levels of anxiety and depression. In our study, we did not find significant differences in the students RCADS MDD levels of depressive symptoms between girls and boys; however, we found significant sex differences in the pupils RCADS GAD scores, with males reporting slightly higher RCADS 
Table 4

\begin{tabular}{|c|c|c|c|c|c|c|}
\hline Variable & $B$ & Std. Error & Beta & $t$ & Sig. & R2Chg \\
\hline \multicolumn{7}{|l|}{ Stage One } \\
\hline $\begin{array}{l}\text { Sex-Dummy Coded } \\
\text { (0: Female,1: Male) }\end{array}$ & .007 & .339 & .001 & .020 & .984 & .000 \\
\hline Stage Two & & & & & & .000 \\
\hline Authoritative & 1.149 & .546 & .085 & 2.104 & $.036^{*}$ & \\
\hline Neglectful & -.235 & .562 & -.017 & -.418 & 676 & \\
\hline Permissive & .874 & .379 & .096 & 2.305 & $.021^{*}$ & \\
\hline \multicolumn{7}{|l|}{ Stage Three } \\
\hline Sex by Authoritative & -1.255 & 1.122 & -.074 & -1.119 & .263 & .000 \\
\hline Sex by Permissive & -.362 & 1.198 & -.022 & -.302 & .762 & \\
\hline Sex by Neglectful & .371 & .768 & .034 & .483 & .629 & \\
\hline
\end{tabular}

Note. $n=710$. All tests of significance for the Change in R2 were conducted using F-tests $* p \leq .05$.

Table 5

Students sex and caregivers parenting styles predicting students RCADS Generalized Anxiety Disorder Scores

\begin{tabular}{|c|c|c|c|c|c|c|}
\hline Variable & $B$ & Std. Error & Beta & $t$ & Sig. & R2Chg \\
\hline $\begin{array}{l}\text { Sex - Dummy Coded. } \\
\text { (0:Female, 1:Male) }\end{array}$ & .674 & .285 & .088 & 2.362 & $.018^{*}$ & .003 \\
\hline Authoritative & -.587 & .460 & -.051 & -1.276 & .203 & \\
\hline Permissive & -.540 & .473 & -.046 & -1.140 & .255 & \\
\hline Neglectful & -.896 & .319 & -.116 & -2.805 & $.005^{*}$ & \\
\hline Sex by Authoritative & -.653 & .944 & -.046 & -.691 & .490 & \\
\hline Sex by Permissive & -.217 & 1.008 & -.015 & -.215 & .830 & \\
\hline Sex by Neglectful & .659 & .647 & .072 & 1.019 & .308 & \\
\hline
\end{tabular}

Note. $n=710$. All tests of significance for the Change in R2 were conducted using F-tests $* p \leq .05$.

GAD scores than females. Additionally, students reported caregiver-parenting styles were associated with their (students) RCADS MDD and GAD. While the regression analyses found that parenting styles affected students reported RCADS GAD scores, it did not advise which types of parenting styles significantly differed in their relation to students anxiety scores.

In keeping with previous research (Abello et al., 2014; Argumedos et al., 2014; Cuevas \& Castro, 2009; Esparza \& Rodríguez, 2009; Velez-Gomez et al., 2013; Vinaccia et al., 2006), our study found no statistically significant correlation between students age and symptoms of youth reported depression or anxiety. However, contrary to former studies (Castilla Puentes et al., 2013; RomeroAcosta et al., 2010; Romero-Acosta et al., 2014), where sex differences were found in Colombian youth such that girls reported more anxiety symptoms than boys, this study found boys to be more anxious. Our sample consisted of grade 5 students, who were in their last year of primary school. Previous international research has shown that the transition for 11 and 12 year old boys into high school can be very anxiety provoking, because they will now have 15 and 16 years old males, in their school environment, with whom they may have contact in such arenas as sporting activities. The reward process asso- ciated with school boy sports tends to reinforce physical aggression that may lead to the development of emasculating stereotypes and bullying (Millington et al., 2008).

\subsection{Prevalence of parenting styles}

The two parenting styles most reportedly used by caregivers of this cohort were authoritative and neglectful parenting style. The former style is characterized by tolerance, acceptance, warmth, and the use of reasonable limits to regulate children's behavior (Baumrind, 1996; Lee et al., 2014), while the latter is related to lower levels of warmth and monitoring (Lipps et al., 2012). These results concur with previous ones (Prieto-Montoya et al., 2016) that found that the parenting style most frequently used in adolescents from Manizales, Colombia, was the authoritative. This finding is unexpected, given the high levels of reported domestic violence in Colombia. We expected that the authoritarian style, characterized by physical yelling, scolding, humiliating, and more physical aggression (Smetana, 2017) would be more reportedly used. It seems that in Sucre, a Colombian department located on the Caribbean coast, children perceive their parental practices as similar to their counterparts in Bahamas, Jamaica, St. Kitts, Nevis and St. Vincent (Lipps et al., 2012). 
Depressive symptoms and parenting styles Similar to prior research (Brassell et al., 2016), parental practices were linked to the presence of internalizing symptomatology, such as depression and anxiety. In this study, students who perceived that their parents used authoritarian or neglectful parenting styles reported more depressive symptoms than those whose parents used authoritative parenting style (Table 3), while those whose parents used authoritative or permissive parenting reported lower depressive symptoms than those whose parents used authoritarian styles (Table 4). Our results are similar to those reported by Lipps et al. (2012), who also found that authoritarian and neglectful parenting styles were more highly associated with childrens levels of depressive symptoms in Jamaica, St. Vincent, St. Kitts and Nevis, than the authoritative style. An authoritarian parental style may have unfavourable effects on childrens adjustment in different cultures, resulting in youth conduct disorder and cognitive problems as well as substance misuse (Lempers et al., 1989; Smith et al., 2011). However, Akinsola (2010) found that parents in Nigeria mainly use a mixture of authoritative and authoritarian parenting styles in caring for their children, where they show love and nurturance to their offspring. However, based on their cultural traditions, they expected obedience and respect for authority figures such as parents and elders in the community.

Children who had neglectful parenting reportedly developed feelings of worthlessness and experienced suicidal ideations in later life (Ehnvall et al., 2008). Parenting practices (such as authoritative and permissive parenting), which included psychological flexibility (an ability to focus on the present and accept discomfort and distress without allowing such negative emotions to direct actions), modelled the same flexibility to the children (Gottman et al., 1996). With psychological flexibility, one attempts to control his or her emotions, thoughts and behaviors by applying certain regulatory strategies. Gottman et al. said (1996) children who receive emotional nurturance from their parents are better able to calm their arousal in situations that provoke strong emotions. Such behaviours lend themselves to better tolerance of negative emotions, a protective factor against depression. In effect, the nurturance demonstrated in authoritative and permissive parenting may model psychological traits which protect children against depression (Brassell et al., 2016).

Anxiety symptoms and parenting styles In keeping with previous research (Lipps et al., 2012; Smetana, 2017), our study found that students caregiver parenting styles related to their (youngster) reported anxiety levels. Based on the results of Table 5, and previous research (Castillo, Carpintero, et al., 2015; Castillo, Sibaja, et al., 2015), students who reported their caregivers used neglectful parenting styles were less anxious than those who reported authoritative parenting. We theorize that our findings may highlight parental nurturance and monitoring (authoritative style) that may be manifested in an anxious manner, which may be learned by their children. This is quite plausible given the high levels of security issues (robberies, assaults, abuses) in the Sucre region (Instituto Nacional de Medicina Legal y Ciencias Forenses, 2016). Kliewer et al. (2004) argued that children exposed to community violence might be at greater risk for the development of internalizing symptoms based on the nature of their parent-child relationships and parents emotion regulation skills. Parents anxious concerns may be transmitted to their children through the caregiver-child interactions, as well as the caregiver regulation of emotion.

Based on these findings, our research has highlighted the need for children ages 8 to 13 years old, who experience authoritative parenting style, to be evaluated for the possible presence of generalized anxiety disorder. Furthermore, pupils ought to be educated about risk factors associated with depression and anxiety, as well as sources of assistance available to them. The school based mental health report of Canada (2013) recommended professional learning in mental health for students, parents, and teachers. It also recommended that there should be adequate numbers of trained mental health professionals in schools, to identify and assist students with mental health problems, such as internalizing disorders, as well as their parents.

\subsection{Limitations}

The results of this study cannot be generalized, firstly because causal inferences cannot be drawn from this cross-sectional study design. This means that a causal directionality of parenting styles to depressive and anxiety symptoms cannot be established. It is possible that children who are depressed or anxious may perceive their parents as neglectful or authoritarian when that may not be the case. Secondly, data obtained are the perceptions of the children; it has not been contrasted with the parents point of view. Thirdly, depressive and anxiety data were obtained only through self-reports; we did not use clinical interviews to diagnosed internalizing disorders. Therefore, students may not have met the diagnostic criteria for internalizing disorders, but reported only symptoms of the disorders. Additionally, children reported on both parents using a single measure. That limited our ability to understand unique associations of mothers versus fathers behavior with child symptoms. Nonetheless, in spite of these limitations, this study has added to the knowledge of Colombian parenting styles (authoritative, authoritarian, neglectful, and permissive), and the associations with students sex, age and symptoms of depression and anxiety. Future research is needed to identify any causal directionality between parenting styles and internalizing disorders among Colombian youth. 


\section{Conclusions}

As previous studies in Colombia (Prieto-Montoya et al., 2016), the two parenting styles most reportedly used by youth in Sincelejo (Sucre) were authoritative and neglectful parenting style. Furthermore, similar to prior research (Brassell et al., 2016; Lipps et al., 2012), parental practices were linked to the presence of internalizing symptoms: students who perceived that their parents used authoritarian or neglectful parenting styles reported more depressive symptoms than those whose parents used authoritative parenting style; and those whose parents used authoritative or permissive parenting reported lower depressive symptoms than those whose parents used authoritarian styles.

\section{Acknowledgements}

This study was supported by a grant from the Corporación Universitaria del Caribe CECAR. The authors thank the study participants, project staff, and research assistants. The authors also thank to the following schools: Institución Educativa Normal Superior de Sincelejo, Colegio San Vicente de Paul, Santa Rosa de Lima, Colegio Policarpa Salavarrieta, Tercer Milenio y Colegio Niño Jesús de Praga. Also, we would like to thank our research assistant Diego Pérez for his effort in collecting parents and children data and to the group of students from El Semillero de Psicología Clínica y de la SaludHOY (SPCS-HOY) for their valuable collaboration in this study.

\section{References}

Abello, D., Cortés, O., Barros, O., Mercado, S., \& Solano, D. (2014). Infantile depression prevalence in barranquilla official schools. Tesis Psicológica, 9(1), 190-201. https://doi.org/10.4314/gab.v8i1.54692.

Akinsola, E. (2010). Correlation between Parenting Styles and Sexual attitudes of Young People in Nigeria: Comparison of Two Ethnic Groups. Gender \&3 Behaviour, 8(1), 2771-2788.

Argumedos, C., Pérez, D., \& Romero Acosta, K. (2014). El estudio de los trastornos emocionales en la infancia colombiana. Búsqueda, 1 (13), 68-61. https://doi.org/10.21892/01239813.157.

Baumrind, D. (1966). Effects of authoritative parental control on child behavior. Child Development, (4), 887-907. https:doi.org/10.2307/1126611.

Baumrind, D. (1971). Current patterns of parental authority. Developmental Psychology, 4(1), 1-103. http://doi.org/10.1037/h0030372.

Baumrind, D. (1996). The discipline controversy revisited. Family Relations, 45(4), 405-414. https://doi.org/10.2307/585170.

Boudreault-Bouchard, A. M., Dion, J., Hains, J., Vandermeerschen, J., Laberge, L., \& Perron, M. (2013).
Impact of parental emotional support and coercive control on adolescents' self-esteem and psychological distress: Results of a four-year longitudinal study. Journal of Adolescence, 36(4), 695-704. https://doi.org/10.1016/j.adolescence. 2013.05.002.

Brassell, A. A., Rosenberg, E., Parent, J., Rough, J. N., Fondacaro, K., \& Seehuus, M. (2016). Parent's psychological flexibility: Associations with parenting and child psychosocial well-being. Journal of Contextual Behavioral Science, 5(2), 111120. https://doi.org/10.1016/j.jcbs.2016.03.001.

Bringuier, S., Dadure, C., Raux, O., Dubois, A., Picot, M., \& Capdevila, X. (2009). The Perioperative Validity of the Visual Analog Anxiety Scale in Children: A Discriminant and Useful Instrument in Routine Clinical Practice to Optimize Postoperative Pain Management.

Brooks, S. (2004). The Kutcher Adolescent Depression Scale (KADS). Child \&3 Adolescent Psychopharmacology News, 9 (5), 4-6. https://doi.org/10.10 89/104454603322572679.

Castilla Puentes, R. C., Gomez Morad, I. S., Castilla Puentes, S. R., Castilla Puentes, W. I., Caballero Badillo, M. C., Puentes de Contreras, G., \& Habeych Sanmiguel, M. E. (2013). Depression, anxiety and somatic complaints in colombian children living in rural communities. Revista de la Universidad Industrial de Santander. Salud, 45(2), 9-19.

Castillo, S., Carpintero, L., Sibaja, D., \& Romero, K. (2015). Estilos de crianza y su relación con sintomatología internalizante en estudiantes de 8 a 16 años. Revista GEPU, 6, 53-65.

Castillo, S., Sibaja, D., Carpintero, L., \& Romero-Acosta, K. (2015). Estudio de los estilos de crianza en niños, niñas y adolescentes en Colombia: Un estado del arte. Búsqueda, 2(15), 64-70. https://doi.org/10.21892/01239813.97.

Chorpita, B. F., Yim, L., Moffitt, C., Umemoto, L. A., \& Francis, S. E. (2000). Assessment of symptoms of DSM-IV anxiety and depression in children: A revised child anxiety and depression scale. $B e-$ haviour Research and Therapy, 38(8), 835-855. https://doi.org/10.1016/s0005-7967(99)00130-8.

Crandall, M., Lammers, C., Senders, C., Savedra, M., \& Braun, J. V. (2007). Initial Validation of a Numeric Zero to Ten Scale to Measure Childrens State Anxiety. Anesthesia and Analgesia, 105(5), 1250-1253. https://doi.org/10.1213/01. ane.0000284700.59088.8b.

Cuevas, M. C., \& Castro, L. (2009). Efectos emocionales y conductuales de la exposición a violencia en niños y adolescentes en Colombia. Psicología Conductual, 17(2), 277-298. 
De La Haye, W., Clarke, T., G., L., Lowe, G., LongmanMills, S., Barton, E. N., \& Bain, B. (2010). The Patterns of Depressive Symptoms among HIV Patients. West Indian Medical Journal, 59(4), 380-385.

de Moor, E. L., Denollet, J., \& Laceulle, O. M. (2018). Social inhibition, sense of belonging and vulnerability to internalizing problems. Journal of Affective Disorders, 225, 207-213.

https://doi.org/10.1016/j.jad.2017.08.034.

Diaconu-Gherasim, L. R., \& Măirean, C. (2016). Perception of parenting styles and academic achievement: The mediating role of goal orientations. Learning and Individual Differences, 49, 378385. https://doi.org/10.1016/j.lindif.2016.06.026.

Duchesne, S., Vitaro, F., Larose, S., \& Tremblay, R. E. (2008). Trajectories of anxiety during elementaryschool years and the prediction of high school noncompletion. Journal of Youth and Adolescence, 37(9), 1134-1146. https://doi.org/10.100 7/s10964-007-9224-0.

Ebesutani, C., Reise, S. P., Chorpita, B. F., Ale, C., Regan, J., Young, J., Higa-McMillan, C., \& Weisz, J. R. (2012). The Revised Child Anxiety and Depression Scale-Short Version: Scale reduction via exploratory bifactor modeling of the broad anxiety factor. Psychological Assessment, 24(4), 833-845. https://doi.org/10.1037/a0027283.

Ehnvall, A., Parker, G., Hadzi-Pavlovic, D., \& Malhi, G. (2008). Perception of rejecting and neglectful parenting in childhood relates to lifetime suicide attempts for females - but not for males. Acta Psychiatrica Scandinavica, 117(1), 50-56. https://doi.org/10.1111/j.1600-0447.2007.01124.x.

Esparza, N., \& Rodríguez, M. C. (2009). Factores contextuales del desarrollo infantil y su relación con los estados de ansiedad y depresión. Diversitas: Perspectivas en Psicología, 51 (1), 47-64.

Ganzeboom, H. G. B., \& Treiman, D. J. (1996). Internationally Comparable Measures of Occupational Status for the 1988 International Standard Classification of Occupations. Social Science Research, 25, 201-239.

Gottman, J. M., Katz, L. F., \& Hooven, C. (1996). Parental metaemotion philosophy and the emotional life of families: Theoretical models and preliminary data. Journal of Family Psychology, 10(3), 243268. https://doi.org/10.1037/0893-3200.10.3.243.

Instituto Nacional de Medicina Legal y Ciencias Forenses. (2016). Forensis. Datos parala vida. Bogotá: Imprenta Nacional de Colombia.

International Labor Office. (1990). International Standard Classification of Occupations: ISCO-88. International Labor Office.

Jules, M. A., Maynard, D.-M. B., Lowe, G., Lipps, G., \& Gibson, R. (2020). A psycho-social analysis of depression, anxiety, and student engagement: Effects of parenting practices. Clinical Child Psychology $\&$ Psychiatry, 26(1), 110-120. https://doi.org/10.1177\%2F1359104520972447.

Kliewer, W., Nelson Cunningham, J., Diehl, R., Adams Parrish, K., M., W. J., Atiyeh, C., Neace, B., Duncan, L., Taylor, K., \& Mejia, R. (2004). Violence Exposure and Adjustment in Inner-City Youth: Child and Caregiver Emotion Regulation Skill, Caregiver-Child Relationship Quality, and Neighborhood Cohesion as Protective Factor. Journal of Clinical Child and Adolescent Psychology, 33(3), 477-487. https://doi.org/10. 1207/s15374424jccp3303_5.

Lee, E. H., Zhou, Q., Ly, J., Main, A., Tao, A., \& Chen, S. H. (2014). Neighborhood characteristics, parenting styles, and children's behavioral problems in Chinese American immigrant families. Cultural Diversity and Ethnic Minority Psychology, 20(2), 202-212. https://doi.org/10.1037/a0034390.

Lempers, J. D., Clark-Lempers, D., \& Simons, R. L. (1989). Economic hardship, parenting, and distress in adolescence. Child Development, 60(1), 25-39. https://doi.org/10.1111/j.1467-8624.198 9.tb02692.x.

Liem, J. H., Cavell, E. C., \& Lustig, K. (2010). The influence of authoritative parenting during adolescence on depressive symptoms in young adulthood: Examining the mediating roles of self-development and peer support. The Journal of Genetic Psychology, 171(1), 73-92. https://doi.org/10.1080/00221320903300379.

Lipps, G., Lowe, G. A., Gibson, R. C., Halliday, S., Morris, A., Clarke, N., \& Wilson, R. N. (2012). Parenting and depressive symptoms among adolescents in four Caribbean societies. Child and Adolescent Psychiatry and Mental Health, 6. Article 31. https://doi.org/10.1186/1753-2000-6-31.

Lipps, G., Lowe, G. A., Halliday, S., Morris, A., Clarke, N., \& Wilson, R. (2010). The Association of Academic Tracking to Depressive Symptoms among High School Students in Three Caribbean Countries. Child and Adolescent Psychiatry and Mental Health, 4. Article16. http://doi.org/10.1186/1753-2000-4-16.

Lipps, G., Lowe, G. A., Morris, A., Halliday, S., Clarke, N., \& Wilson, R. N. (2009). School factors associated with depression in a Jamaican high school cohort. Journal of Black Psychology, 36(3), 369-380.

Lowe, G. A., Lipps, G., \& Young, R. (2009). Factors Associated with Depression Among Students of the University of the West Indies - Mona. West Indian Medical Journal, 58(1), 21-27. 
Măirean, C., \& Diaconu-Gherasim, L. R. (2020). Depressive Symptoms and Achievement Goals: Parental Rejection as a Moderator. The Journal of Early Adolescence, 40(9), 1369-1396.

https://doi.org/10.1177/0272431619858417.

Maharaj, R. G., Alli, F., Cumberbatch, K., Laloo, P., Mohammed, S., Ramesar, A., Rampersad, N., Roopnarinesingh, N., \& Ramtahal, I. (2008). Depression among Adolescents, Aged 13-19 Years, attending Secondary Schools in Trinidad: Prevalence and Associated Factors. West Indian Medical Journal, 57(4), 352-359.

Masi, G., Sbrana, B., Poli, P., Tomaiuolo, F., Favilla, L., \& Marcheschi, M. (2000). Depression and school functioning in non-referred adolescents: A pilot study. Child Psychiatry and Human Development, 30 (3), 161-171. https://doi.org/10.1023/A:1021395504617.

Millington, B., Vertinsky, P., Boyle, E., \& Wilson, B. (2008). Making Chinese-Canadian masculinities in Vancouver's physical education curriculum. Sport, Education and Society, 13(2), 195-214. https://doi.org/10.1080/13573320801957095.

Ministerio de Tecnologías de la Información y las Comunicaciones. (2020). Instituciones educativas del municipio de sincelejo del año 2017.

https://www.datos.gov.co/Educaci-n/INSTITUCIONES-EDUCATIVAS-DEL-MUNICIPIO-DESINCELEJ/v9zf-2vpf .

Moreno-Méndez, J. H., Espada-Sánchez, J. P., \& GómezBecerra, M. I. (2020). Role of parenting styles in internalizing, externalizing, and adjustment problems in children. Salud Mental, 43(2), 7384.

https://doi.org/10.17711/sm.0185-3325.2020.011.

Norris, C., Pignal, J., \& Lipps, G. (2003). Measuring school engagement. Education Quarterly Review, $9(2), 25-34$.

Ospina-Ospina, F. C., Hinestrosa-Upegui, M. F., Paredes, M. C., Guzmán, Y., \& Granados, C. (2011). Síntomas de ansiedad y depresión en adolescentes escolarizados de 10 a 17 años en Chía, Colombia. Revista de Salud Pública, 13(6), 908-920. https://doi.org/10.1590/S0124-0064201100060 0004.

Pérez Vásquez, D., Regino Torres, T., Gómez Oyola, N., Castillo Santis, S., \& Romero-Acosta, K. (2016). Presencia de sintomatología ansiosa en niños, niñas y adolescentes de 8 a 16 años de edad en Sincelejo (Sucre): Una comparación entre hijos de desplazados y de no desplazados. Psicoespacios, 10(17), 51-70.

https://doi.org/10.25057/21452776.802.

Pinquart, M. (2017). Associations of parenting dimensions and styles with externalizing problems of children and adolescents: An updated meta-anal- ysis. Developmental psychology, 53(5), 873-932. https://doi.org/10.1037/dev0000295.

Polcari, A., Rabi, K., Bolger, E., \& Teicher, M. H. (2014). Parental verbal affection and verbal aggression in childhood differentially influence psychiatric symptoms and wellbeing in young adulthood. Child Abuse \& Neglect, 38(1), 91-102. https://doi.org/10.1016/j.chiabu.2013.10.003.

Prieto-Montoya, J. A., Cardona-Castañeda, L. M., \& Vélez-Álvarez, C. (2016). Estilos parentales y consumo de sustancias psicoactivas en estudiantes de $8^{\circ}$ a $10^{\circ}$. Revista Latinoamericana de Ciencias Sociales, Niñez y Juventud, 14 (2), 13451356.

Revah-Levy, A., Birmaher, B., Gasquet, I., \& Falissard, B. (2007). The Adolescent Depression Rating Scale (ADRS): a validation study. BMC Psychiatry, 7(2). Article 2. https://doi.org/10.1186/1471-244X-7-2.

Romero-Acosta, K., Canals, J., Hernández-Martínez, C., Jané Balladriga, M. C., Viñas, F., \& DomènechLlaberia, E. (2010). Comorbilidad entre los factores de ansiedad del SCARED y la sintomatología depresiva en niños de 8-12 años. Psicothema, 22 (4), 613-618.

Romero-Acosta, K., Penelo, E., Noorian, Z., Ferreira, E., \& Domènech-Llaberia, E. (2014). Racial/ethnic differences in the prevalence of internalizing symptoms: Do Latin-American immigrant show more symptomatology than Spanish native-born adolescents? Journal of Health Psychology, 19(3), 381-392. https://doi.org/10.1177/1359105312471568.

Rothenberg, W. A., Lansford, J. E., Al-Hassan, S. M., Bacchini, D., Bornstein, M. H., Chang, L., DeaterDeckard, K., Di Giunta, L., Dodge, K. A., Malone, P. S., Oburu, P., Pastorelli, C., Skinner, A. T., Sorbring, E., Steinberg, L., Tapanya, S., Maria Uribe Tirado, L., Yotanyamaneewong, S., \& Peña Alampay, L. (2020). Examining effects of parent warmth and control on internalizing behavior clusters from age 8 to 12 in 12 cultural groups in nine countries. Journal of Child Psychology and Psychiatry and Allied Disciplines, 61(4), 436-446. https://doi.org/10.1111/jcpp.13138.

Scharf, M., Mayseless, O., \& Rousseau, S. (2016). When somatization is not the only thing you suffer from: Examining comorbid syndromes using latent profile analysis, parenting practices and adolescent functioning. Psychiatry Research, 244, $10-18$.

https://doi.org/10.1016/j.psychres.2016.07.015. Smetana, J. G. (2017). Current research on parenting styles, dimensions, and beliefs. Current Opinion 
in Psychology, 15, 19-25.

https://doi.org/10.1016/j.copsyc.2017.02.012.

Smith, D. E., Springer, C. M., \& Barrett, S. (2011). Physical discipline and socioemotional adjustment among jamaican adolescents. Journal of Family Violence, 26(1), 51-61. https://doi.org/ 10.1007/s10896-010-9341-5.

Steinberg, L., Lamborn, S. D., Darling, N., Mounts, N. S., \& Dornbusch, S. M. (1994). Over-time changes in adjustment and competence among adolescents from authoritative, authoritarian, indulgent, and neglectful families. Child Development, 65(3), 754-770. https://doi.org/10.1111/j.14678624.1994.tb00781.x.

Van Der Bruggen, C. O., Stams, G. J., \& Bögels, S. M. (2008). Research review: The relation between child and parent anxiety and parental control: A meta-analytic review. Journal of child psychology and psychiatry, and allied disciplines, 49(12), 1257-1269. https://doi.org/10.1111/j.14 69-7610.2008.01898.x.

Varela, R. E., Sanchez-Sosa, J. J., Biggs, B. K., \& Luis, T. M. (2009). Parenting strategies and sociocultural influences in childhood anxiety: Mexican, Latin American descent, and European American families. Journal of anxiety disorders, 23(5), 609-616.

https://doi.org/10.1016/j.janxdis.2009.01.012.

Velez-Gomez, P., Restrepo-Ochoa, D. A., Berbesi-Fernandez, D., \& Trejos-Castillo, E. (2013). The spanish journal of psychology, 16. Article E64. https://doi.org/10.1017/sjp.2013.71.

Vinaccia, S., Gaviria, A. M., Atehortúa, L. F., Martínez, P. H., Trujillo, C., \& Quiceno, J. M. (2006). Prevalencia de depresión en niños escolarizados entre 8 y 12 años del oriente antioqueño a partir del Child Depression Inventory-CDI. Diversitas: Perspectivas en Psicología, 2(2), 217-227. https://doi.org/10.15332/s1794-9998.2006.0002.03.

Wesselhoeft, R., Sørensen, M. J., Heiervang, E. R., \& Bilenberg, N. (2013). Subthreshold depression in children and adolescents. A systematic review. Journal of Affective Disorders, 151(1), 722. https://doi.org/10.1016/j.jad.2013.06.010. 


\section{Appendix A}

Suplemental Material: Spanish questionnaire

Factores Sociales y Emocionales en Estudiantes del Grado quinto Fase 1
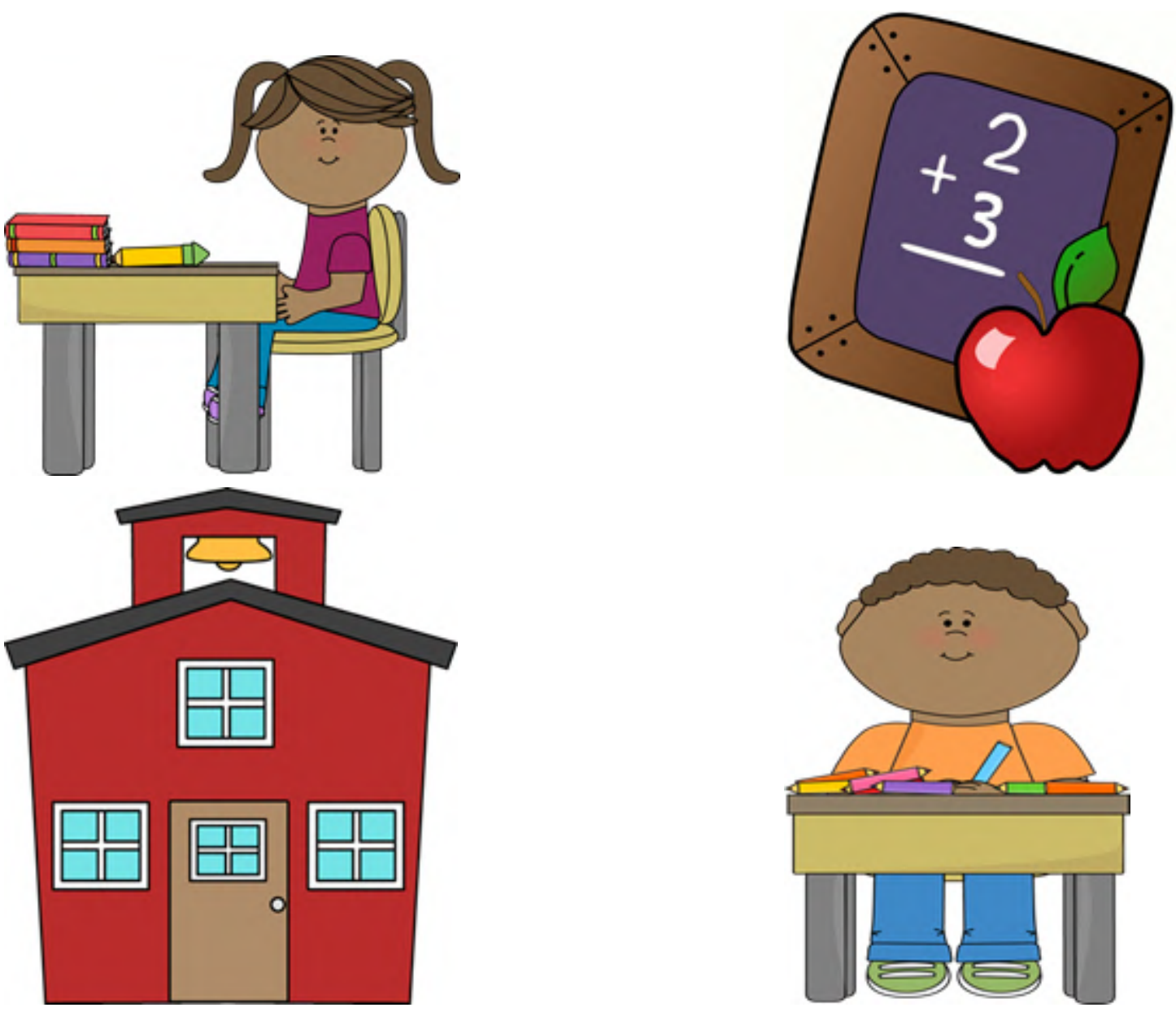

En las siguientes páginas te preguntaremos acerca de tus emociones y sobre cómo te sientes. Todas las respuestas a este cuestionario se mantendrán bajo estricta confidencialidad.

Estas primeras preguntas indagan sobre cómo te sientes acerca del colegio, lo bien que lo estás haciendo y sobre tus opiniones sobre el colegio.

1. ¿Cómo te sientes acerca del colegio?
a. Me encanta el colegio
b. Me gusta mucho el colegio
c. Me gusta un poquito el colegio
d. No me gusta mucho el colegio
e. Odio el colegio

2. ¿Qué tan bien crees que estás haciendo el trabajo escolar?
a. Muy bien
b. Bien
c. Más o menos
d. Mal
e. Muy mal 
3. ¿Qué tan importante es para ti hacer las siguientes cosas en el colegio?

$\begin{array}{cr}\text { Muy } & \text { Impor } \\ \text { Importante } & \\ 1 & 2 \\ 1 & 2 \\ 1 & 2\end{array}$

importante De algún modo
importante

No muy No del todo importante importante

2

2

1

12

12

1

1
3

3

3

3

3

3

3

3
5

5

5

5

5

5

5 a. Hacer amigos

b. Obtener buenas calificaciones

c. Participar en actividades extra curriculares

d. Aprender cosas nuevas

e. Siempre llegar a tiempo a clase

f. Expresar tu opinión en clase

g. Hacer parte del consejo de estudiantes y participar en otras cosas

h. Entregar las tareas a tiempo
4. ¿Con qué frecuencia hablas con el profesor fuera de clase?
a. Todos los días
b. Algunas ves a la semana
c. Una vez a la semana
d. Algunas veces al mes
e. Menos de una vez a la semana
f. Nunca 
Las siguientes preguntas indagan sobre algunas actividades que te gusta hacer

En los últimos 12 meses con qué frecuencia tú...

1. Practicas deporte con un instructor,

(Clases de natación, fútbol, voleibol, etc.)?

2. Haces parte de clases de gimnasia, karate u otras lecciones?

3. Haces parte de grupos de arte, drama o grupos musicales, o algún tipo de club fuera del colegio?

4. Haces parte de algún club o grupo como los Scouts, un grupo comunitario, la iglesia u otro grupo religioso?

5. Te dedicas a un hobby o manualidad (dibujar, construir maquetas?

$\begin{array}{cccc}\text { Nunca } & \begin{array}{r}\text { Menos de } \\ \text { una vez a } \\ \text { la semana }\end{array} & \begin{array}{c}\text { De } 1 \text { a } 3 \\ \text { veces a } \\ \text { la semana }\end{array} & \begin{array}{c}\text { 4 o más } \\ \text { veces a } \\ \text { la semana }\end{array} \\ 1 & 2 & 3 & 4 \\ 1 & 2 & 3 & 4 \\ 1 & 2 & 3 & 4 \\ 1 & & 3 & 4 \\ 1 & & & 4\end{array}$

Las siguientes preguntas buscan conocer cómo te sientes generalmente y cómo te sientes ahora. Por favor encierra el número que mejor describa qué tan nervioso o ansioso te sientes.

1. Por favor encierra el número que mejor describa qué tan nervioso o ansioso te sientes ahora.

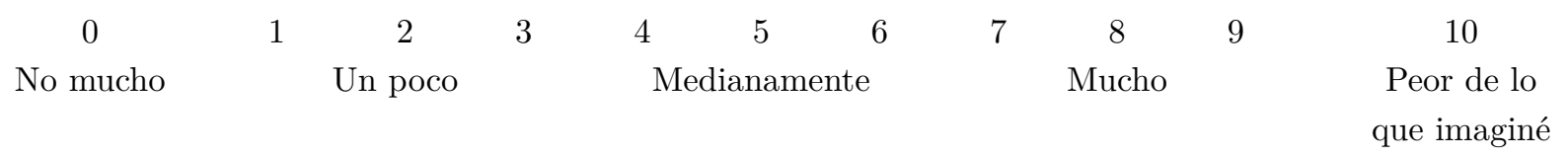

2. Por favor encierra el número que mejor describa qué tan nervioso o ansioso te sentiste durante las últimas seis semanas.

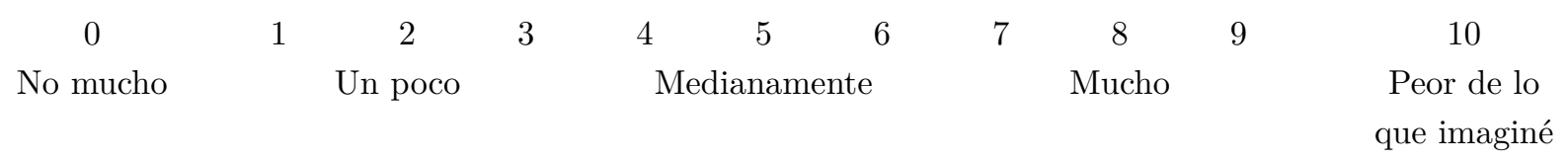

3. Por favor, coloca una marca en la línea que mejor describa lo ansioso o temeroso que te sientes ahora.

Sin ansiedad

o miedo
La peor ansiedad

o miedo posible

4. Por favor, coloca una marca en la línea que mejor describa lo ansioso o temeroso que te sentiste en los últimos 6 meses.

Sin ansiedad

o miedo

La peor ansiedad

o miedo posible

Las siguientes preguntas buscan conocer acerca de cómo te sientes generalmente. Por favor, encierra la palabra que mejor describa lo nervioso o ansioso que te sientes generalmente.

1. Me preocupo por las cosas.

Nunca

A veces

Con frecuencia

Siempre

2. Me preocupa que le suceda algo feo a

Nunca

$A$ veces

Con frecuencia

Siempre alguno de mis familiares.

3. Me preocupa que me sucedan cosas malas

Nunca

A veces

Con frecuencia

Siempre 
4. Me preocupa que algo malo me suceda.

Nunca A veces

Con frecuencia

Siempre

5. Me preocupa lo que va a pasar.

Nunca

A veces

Con frecuencia

Siempre

6. Pienso en la muerte.

Nunca

A veces

Con frecuencia

Siempre

Ahora nos gustaría hacerte algunas preguntas acerca de qué tan triste o irritable te sientes. Por favor haz un círculo en la palabra que muestre con qué frecuencia te suceden estas cosas. No existen respuestas correctas o incorrectas.

1. Me siento triste y vacío.

2. Ya nada es divertido.

3. Tengo problemas para dormir.

4. Tengo problemas de apetito.

5. No tengo energía para hacer las cosas.

6. Estoy muy cansado.

7. No puedo pensar claramente.

8. Me siento inútil.

9. Me siento como si no quisiera moverme.

10. Me siento inquieto.

$\begin{array}{ll}\text { Nunca } & \text { A veces } \\ \text { Nunca } & \text { A veces } \\ \text { Nunca } & \text { A veces } \\ \text { Nunca } & \text { A veces } \\ \text { Nunca } & \text { A veces } \\ \text { Nunca } & \text { A veces } \\ \text { Nunca } & \text { A veces } \\ \text { Nunca } & \text { A veces } \\ \text { Nunca } & \text { A veces } \\ \text { Nunca } & \text { A veces }\end{array}$

Con frecuencia

Siempre

Con frecuencia

Siempre

Con frecuencia

Siempre

Siempre

Siempre

Con frecuencia

Siempre

Siempre

Siempre

Siempre

Siempre

A continuación se presentan una series oraciones que describen la manera cómo te sientes. Por favor encierre la oración que sea falsa o verdadera para ti. No existen respuestas correctas o incorrectas.

1. No tengo energía para el colegio.

2. Tengo problemas al pensar.

3. Me siento abrumado por la tristeza y la inquietud.

4. Nada me interesa o me entretiene.

5. Lo que hago es inútil.

6. Cuando me siento así quisiera estar muerto.

7. Todo me molesta.

8. Me siento abatido y desanimado.

9. Duermo mal.

10. Ahora no me interesa el colegio, no puedo hacerle frente.

$\begin{array}{ll}\text { Verdadero } & \text { Falso } \\ \text { Verdadero } & \text { Falso } \\ \text { Verdadero } & \text { Falso } \\ & \\ \text { Verdadero } & \text { Falso } \\ \text { Verdadero } & \text { Falso } \\ \text { Verdadero } & \text { Falso } \\ \text { Verdadero } & \text { Falso } \\ \text { Verdadero } & \text { Falso } \\ \text { Verdadero } & \text { Falso } \\ \text { Verdadero } & \text { Falso }\end{array}$

Falso

Falso

Falso

Falso

Falso

Falso

Falso 


\section{Cómo has estado durante la última semana, "en promedio" o "usualmente" con relación a los siguientes temas:}

$\begin{array}{cccc}\text { Casi nunca } & \text { La mayoría } & \text { La mayoría } & \text { Todo el } \\ & \text { del tiempo } & \text { de las veces } & \text { tiempo }\end{array}$

1. Bajo de ánimo, triste, desganado para hablar,

1 deprimido, no has querido ser molestado.

2. Irritable, enfadado, has perdido el humor fácilmente.

3. Con problemas para dormir - diferente de lo normal (durante los años antes de enfermarte): problemas para conciliar el sueño quedándote despierto en la cama.

4. Con menos interés en: salir con los amigos; estar con tu mejor amigo; estar con tu novio/novia; salir de la casa; hacer tareas o trabajar; practicar hobbies o deportes o recreación.

5. Te has sentido inútil, desesperado, has decepcionado a la gente, has dejado de ser buena persona.

6. Sensación de cansancio, sensación de fatiga, baja en energía, dificultad para estar motivado, te deben presionar para hacer las cosas, quieres descansar o estar acostado todo el tiempo.

7. Dificultad para concentrarse, no puedes mantener tu mente en el trabajo o en el colegio, sueñas despierto cuando deberías estar trabajando, se te hace difícil concentrarte en la lectura, te aburres con el trabajo o la escuela.

8. Sientes que la vida no es muy divertida, no te sientes tan bien como usualmente lo haces (antes de enfermarte) no sientes placer por cosas divertidas como usualmente lo haces (antes de enfermarte).

9. Preocupación, nerviosismo, pánico, tensión, excitación, ansiedad.

10. Molestias físicas debido a la preocupación tales como: dolor de cabeza, mariposas en el estómago, náuseas, sensación de hormigueo, inquietud, diarrea, sacudidas o temblores.
1

2

3

1

1

1

2

3

1

2

3

4

1

2

3

4

1
4

4

4

4

4

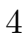

4 4

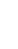

4

11. Has tenido pensamientos, planes o acciones para suicidarte o hacerte daño a ti mismo
a. sin pensamientos o planes o acciones
b. pensamientos ocasionales, no hay planes o acciones
c. pensamientos frecuentes, no hay planes o acciones
d. planes y/o acciones que han hecho dañado 
La siguiente sección del cuestionario se pregunta sobre cómo te llevas con tus padres o tutores

1. Mis padres (o padrastros o padres adoptivos)

Nunca Raramente A veces

a. Olvidan pronto una regla que ellos han impuesto.

b. Me castigan por hacer algo malo un día, pero lo olvidan al día siguiente.

c. Dependiendo de su estado de ánimo hacen cumplir una regla o no.

d. Me regañan por cosas pequeñas.

e. Me pegan o amenazan.

f. Mantienen reglas solo cuando les conviene.

g. Se enojan y me gritan.

h. Me han golpeado.

i. Amenazan con castigarme más de lo usual.

j. Me dan mucho cuidado y atención.

k. Escuchan mis ideas y opiniones.

l. El centro de sus vidas soy yo.

m. Están interesados en lo que aprendo en el colegio.

n. Se interesan por saber dónde estoy y con quién.

o. Quieren saber exactamente dónde voy que hago.

p. Averiguan sobre mi mal comportamiento.

q. Me dicen la hora que debo llegar a casa cuando salgo.

r. Me dejan salir las noches que quiero.

s. Me supervisan y vigilan.

t. Me sonrien.

u. Me elogian.

v. Hablan de las cosas buenas que hago.

w. Parecen orgullos de las cosas que hago.

x. Se aseguran de que me sienta apreciado.

y. Me compensan con privilegios adicionales.

z. Se interesan por entender cómo veo las cosas.

aa. Me dan la oportunidad de escoger que hacer cuando es posible.

bb. Cada vez que no estamos de acuerdo en algo, tratamos de resolverlo juntos.

cc. Cuando discutimos, nos quedamos bravos por largo tiempo.
Con

frecuencia

4

4

4

5

5

5

5

5

5

5

5

5

5

5

5

5

5

5

5

5

5

5

5

5

5

5

5

5

5

5 
Las siguientes preguntas reúnen cierta información sobre ti y tu familia. Esta información se recoge con el fin de entender cómo los niños de diferentes edades, géneros y clases sociales se sienten y se relacionan con los demás.

1. ¿ Cuál es tu género?
a. Femenino
b. Masculino

2. ¿Cuál era su edad en tu último cumpleaños?

Años

3. ¿Cuál es la ocupación actual de tu mamá?

4. ¿Cuál es el nivel de educación de tu mamá?
a. Sin escolarización.
b. Jardín infantil.
c. Primaria.
d. Bachillerato.
e. Técnica en el Sena u otros.
f. Universitaria.
g. Con Postgrado

5. ¿Cuál es la ocupación actual de tu papá?

6. ¿Cuál es el nivel de educación de tu papá?
a. Sin escolarización.
b. Jardín infantil.
c. Primaria.
d. Bachillerato.
e. Técnica en el Sena u otros.
f. Universitaria.
g. Con Postgrado 


\section{Comentarios}

Por favor, siéntete libre de utilizar el espacio de abajo para expresar cualquier inquietud o comentario con respecto a este proyecto. 